\title{
Domestic Energy Needs and Natural Resources Conservation: The Case of Fuelwood Consumption in Nigeria
}

\author{
Momodu, I. Momodu \\ Economic Policy Research Department, \\ Nigerian Institute of Social and Economic Research (NISER), Ibadan-Nigeria
}

\section{Doi:10.5901/mjss.2013.v4n8p27}

\begin{abstract}
Apart from air, water and food, energy is the most important item for human survival. It is essential for meeting various domestic, industrial and commercial obligations. Kerosene, electricity, gas and fuelwood are however, the major sources of domestic energy in Nigeria. The paper examines the role and challenges associated with the use of fuelwood in Nigeria. Desk research on energy utilisation, rate of deforestation and alternative sources of energy provided data for the paper. Content analysis of available data was used in the preparation of the paper. The paper revealed that domestic energy accounts for more than 50 per cent of the total energy consumed in Nigeria. The paper further shows that fuelwood provides energy for more than 60 per cent Nigerians and also responsible for meeting 80 per cent of domestic energy needs. Again, majority of Nigerians adopted fuelwood for meeting domestic energy needs due to the high level of poverty, inadequate infrastructure and lack of political-will to address the country's energy challenges. The paper therefore recommends the use of gas, kerosene and electricity for domestic needs in order to conserve the nation's forest resources, prevents loss of biodiversity and conserve the ground water.
\end{abstract}

Keyword: domestic energy, fuelwood, Nigeria

\section{Introduction}

Energy is a basic necessity of life for meeting domestic, social and industrial needs. Adequate and regular energy supply for industrial and domestic purposes are prerequisites for keeping socio-economic life moving. Energy is required at all times for meeting various purposes especially at the household levels. Life becomes difficult and meaningless without the availability of adequate and regular energy supply for domestic needs.

Energy for domestic purposes is determined by two major factors: availability and affordability. This implies that energy must be readily available and the price must be within the reach of the people especially the poor. Making energy available to all and sundry in a particular society is a measure of level of economic development of that particular society. For example, in advanced economies like UK, USA and France, majority of their population have access to cheap and affordable energy supply because they are technologically advanced. The necessary energy infrastructures are available while the costs of energy are affordable by the majority of the people.

The reverse is however the case with people living in low income country like Nigeria, where the purchasing power of large proportion of the populace is low while necessary energy infrastructure are not in place. Thus, majority of the people do not have access to energy sources of their choice. In addition, there is lack of adequate energy infrastructure and adequate energy supply. This further compounds the problems of energy availability. Overall, most of the developing nations do not have access to cheap, reliable and environmentally friendly energy sources.

This paper aims at discouraging the use of fuelwood for domestic energy needs in order to protect the 
nation's forest resources with a view to reduce global warming. This paper was prepared through content analysis of data obtained from various published materials.

\section{Sources of Domestic Energy in Nigeria}

Nigeria is a developing economy with human population of about 144 million and total land area of 923.8 square kilometers (World Development Indicators, 2006)). The population of urban dwellers is about 67 million (48 per cent) while that of rural dwellers is 73 million (52 per cent). The implication of this demographic structure is that large amount of energy will be required for meeting obligations at both the urban and rural areas in the country.

The rural dwellers, whose needs are often basic, depend to a large extent on the traditional sources of energy for their domestic energy requirements while the majority of the urban dwellers depend on traditional energy sources and fossil fuels. However, the high level of poverty and other socio-economic problems inhibit both the rural and urban dwellers from having access to adequate and reliable sources of energy for domestic purposes.

In terms of energy availability, there are various ample energy sources in Nigeria such as wind, solar, hydro, coal, oil and gas etc, which if properly managed will alleviate energy problems of the people most especially for domestic consumption. Obviously, Nigeria is naturally endowed with oil and gas and depends on it for her economic development. For example, oil accounts for 80.5 per cent of national revenue (CBN, 2007). These two energy sources are the major export commodities that provide foreign exchange for the country. Oil and gas also play major role in meeting energy needs of the various sectors of the nation's economy. For example, gas, petrol, diesel and kerosene provide energy for wide industrial and domestic application.

Apart from oil and gas, other energy sources such as electricity, wood and coal also play significant roles in meeting energy demands in the country. However, among all these energy sources, only fuelwood is mostly available and utilized almost everywhere in the country for meeting domestic energy needs. Other energy sources are scarce most especially in the rural areas where fuelwood is their major energy carrier.

Adetunji (2007) opined that energy option of any country is influenced by national economic condition, individual level of income, technological advancement, the state of energy infrastructure as well as the rate of population growth. The Nigerian energy sector is not well developed based on the fact that despite abundance various energy sources in the country, majority of the people are yet to have access to affordable and reliable energy. Iwayemi (2008) opined that Nigerian energy sector is probably one of the most inefficient in meeting the energy needs of its people. This is most evident in persistent disequilibrium in the market for electricity and petroleum products, especially kerosene and premium motor spirit (PMS).

The energy dependent sectors of Nigerian economy are domestic, transport, industry, agriculture and commerce. Apart from their energy intensiveness, the periodic total energy demand of each of these sectors varies. In addition, the source(s) of energy for the various sectors also differs. For example, the transport sector depends on the premium motor spirit (PMS) for light vehicles such as cars and buses, automotive gas oil (AGO) for heavy-duty vehicles (lorries and trucks) and rail engines. It is estimated that 74 per cent of local petroleum products supply is consumed by the transport sector in the country (Sambo, 2005). The industrial sector depends on electricity, diesel and gas for meeting their energy needs while the agricultural sector depends on AGO and gas for propelling machine in fertilizer production. The household sector which requires large amount of energy for cooking, boiling, heating and lighting however depends mostly on fuelwood and partially on electricity and kerosene in many countries across the globe.

\section{The Significance of Domestic Energy}

The significance of domestic energy in the overall well-being of the people cannot be over-emphasized. The 
various household energy requirements account for the largest quantity of energy consumed among all the other sectors of the economy. This is based on the fact that energy is required for cooking, lighting, heating, boiling, and operation of various domestic appliances among other needs. More so, energy is required almost throughout the day for running these appliances and for lighting. In addition, various categories of people (adult and children) spend most of their time at home and hence depend on energy to make their lives at home comfortable. The level of consumption of domestic energy varies across the globe. In most of the Organization for Economic Cooperation and Development (OECD) countries for example, domestic energy consumption accounts for 40 per cent of total energy use (Kerby, 2008). This figure will increase due to rapid rate of construction in both developing and developed countries. However, heating, lighting, domestic appliance use and cooling equipment gulped 11 per cent of global energy figure (Kerby, 2008).

In developing countries like Nigeria, the level of domestic energy consumption is also the highest among all the other sectors of the economy. The domestic sector consumed more than half of the total energy consumption in Nigeria (Ikuponisi, 2006). Earth Trends also estimates the Nigerian domestic energy consumption figure in 1999 to be 79.5 per cent of total national energy consumption. The energy commission of Nigeria (ECN, 2003) stated that domestic sector accounts for over 50 per cent of the grid electricity consumed and more than 50 per cent of the total energy produced in the country. The sector is therefore the highest energy consumer in the country because it gulps more than half of the total energy supply in the country.

\section{The Role Of Fuel Wood In Energy Supply In Nigeria}

Fuel wood has been a major source of energy for many countries across the globe for several years back. It is the oldest energy source in most of the developing countries worldwide. The high level of poverty, inadequate knowledge about other energy sources as well as other social diseases are responsible for the adoption of fuelwood as a major energy source in many countries of the world. This scenario has continued to exist in poor countries that lack the required technology and resources to adopt and utilize other energy sources.

Developed nations rely on electricity, gas and solar energy for meeting their domestic energy needs. Serious intensification of technological advancement effort has led to the identification, exploitation and utilization of other energy sources in most of the technologically advanced countries. As a result, various energy sources such as nuclear, wind, solar among others are developed and utilized for the generation of energy. Globally, more than 2 billion people depend on fuel wood for meeting their energy needs (Adetunji , et al, 2007). Almost all African countries rely on fuelwood for meeting their domestic energy needs (Sambo, 2005). In addition, fuel wood had a share of between 60 and 86 per cent of African energy consumption, except South Africa. In most of the countries in Sub Sahara Africa, fuel wood accounts for 80 to 90 per cent of residential energy consumption.

One major energy problem confronting the developing countries like Nigeria is that majority of their people lack access to energy sources and therefore mostly depended on fuelwood for most of their energy needs. Most of the rural dwellers in Nigeria depend on fuelwood for their energy. Fuelwood is used by more than 60 per cent Nigerians living the rural areas (Sambo, 2005).

Apart from domestic energy purposes, fuelwood is also used in other sector of the economy such as cottage industries. For example, in most of the bakery industry, fuelwood is used for providing heat for baking bread. More importantly, fuelwood is used mostly in cooking large quantity of several food items used in social occasions in the country. Nigerians consume over 50 million metric tons of fuel wood annually, a rate, which exceeds the replenishment rate through various afforestation programmes (Sambo, 2006).

Table 1 shows the level of consumption of fuelwood for meeting energy needs in Nigeria. The table shows an increase in the level of production and utilization of fuelwood for domestic and industrial purposes. A critical analysis of the table shows that between 1997 and 2006 (a ten year period), about 23,787 thousand 
cubic meter of fuelwood was the marginal increase in the level of fuelwood consumption for meeting domestic energy needs in the country. In addition, the table shows a steady percentage increase of 72.3 per cent in the yearly fuelwood consumption for domestic energy purpose. Fuelwood is therefore playing a very significant role in domestic energy needs in the country.

Table 1: Fuelwood Consumption Pattern in Nigeria (Thousand Cubic Metres)

\begin{tabular}{|c|c|c|c|c|}
\hline Year & Total Production & Household Consumption & Percentage of Total Production & Industrial Consumption \\
\hline 1997 & 152433 & 110194 & 72.3 & 31069 \\
\hline 1998 & 156500 & 113134 & 72.3 & 31897 \\
\hline 1999 & 156516 & 113145 & 72.3 & 31901 \\
\hline 2000 & 160272 & 115861 & 72.3 & 32666 \\
\hline 2001 & 163959 & 118526 & 72.3 & 33418 \\
\hline 2002 & 167973 & 121428 & 72.3 & 34236 \\
\hline 2003 & 172098 & 124410 & 72.3 & 35077 \\
\hline 2004 & 175884 & 127147 & 72.3 & 35848 \\
\hline 2005 & 179754 & 129944 & 72.3 & 36667 \\
\hline 2006 & 185357 & 133981 & 72.3 & 37789 \\
\hline
\end{tabular}

Source: Energy Statistics Database: United Nations Statistical Division (2008)

Fuelwood has assumed a major role as domestic energy source in Nigeria as a result of several factors such as poor state of the economy, inadequate infrastructure and lack of good political will. Among all these problems, the poor state of Nigerian economy is the most significant problem confronting majority of the people (Sambo, 2005). The poor condition of Nigerian economy which manifests in form of widespread poverty has several implications on the people.

In the first instance, poverty is a social disease that affects large section of the Nigerian populace with numerous impacts on the socioeconomic well being of the people. Secondly, poverty is a multi-dimensional social malady that cut across the several ways of life of the people such as feeding habits, style of dressing and overall living standards including their choice of energy. About 70.8 per cent Nigerians are poor, living below US\$1.00/day (World Development Report, 2007/2008). This condition forces majority of the poor to depend on fuelwood for energy since they could not afford other energy sources like kerosene, gas and coal regularly. The rural poor for example, only need to travel for a short distance from their home, to collect fuelwood. The rural poor for example, only need to travel for a short distance from their home, to collect fuelwood for meeting their domestic energy needs without any financial implication. More importantly, many people have resulted into cutting, collection and gathering of fuelwood as employment opportunity and means of livelihood. This situation is very common in most of the rural areas in Nigeria where jobless youths and adult (male and female) have adopted gathering of fuelwood as a major employment to complement their farming and other petty trading activities.

In addition, poor state of social infrastructure has become a clog in the distribution of energy to all parts of the country. The infrastructural problems such as poor distribution of petroleum products, lack of good road network, inadequate generation and distribution of electricity among other things inhibits several millions of Nigerians from having access to social services. This situation forced majority of Nigerians to adopt fuelwood for meeting their domestic energy needs and so adversely affects their living condition. Poor infrastructural facility has contributed largely to increase in the level of poverty in this country. As a result, large proportion of the rural dwellers, do not have access to electricity, pipe-borne water and energy goods. They depend on streams and wells for water supply and fuelwood for their energy needs.

The prevailing poor road network of the country inhibits many people from having access to energy goods. Lack of good roads contributed to increase in the prices of goods in the country. This makes prices of 
kerosene and other energy goods to rise beyond the reach of the poor. The only alternative left for the poor is to adopt fuelwood for their energy needs.

The inadequate state of electric power generation and poor distribution system in the country also limits majority of Nigerian citizens to the use of fuelwood for meeting their domestic needs. More importantly, the supply and distribution of petroleum products in the country is not encouraging. Many people cannot afford to buy kerosene for their domestic purpose. Where the product is available, it is sold at prices more than 50 per cent above what the urban dwellers are paying.

Inadequate and poor condition of infrastructure, especially, the energy infrastructure prevents people from getting regular supply of energy in Nigeria. For example, the four public refineries and private ones in the country cannot guaranteed adequate production of petroleum products for local consumption. In addition, there are inadequate number of petroleum products depots and vehicular transportation to handle the products storage and distribution to all parts of the country. This situation also contributes to increase in the prices of petroleum products and therefore forces the poor to adopt fuelwood for their energy needs.

Absence of good political-will to deliver essential goods to the people is another reason why many Nigerians adopt fuelwood as their major energy source. On many occasions, there is inadequate supply of petroleum products in the country. Also, under the aegis of deregulation, the prices of energy sources often go up beyond the reach of the poor. The federal government of Nigeria (FGN) has carried out upward deregulation of the petroleum products prices in order to raise its revenue and reduce level of subsidization. This condition has forced the prices to go up thereby forcing so many people to adopt fuelwood as their energy source.

Absence of good governance can also translate to social unrests and criminalities. A lot of social infrastructures were vandalized in Nigeria due to government's insensitivity to the plights of the people. For instance, on many occasions, electricity, gas and oil infrastructure such as cables, transformers pipelines and installations were vandalized thereby leading to artificial scarcity of energy thus forcing people to adopt fuelwood to meet their energy needs.

\section{The Ecological, Health and Economic Implications of Using Fuelwood for Domestic Energy}

The use of fuelwood for meeting domestic energy needs has several ecological, health and economic implications. All these have significant impact on man's social life because human live greatly depends on them. It is obvious to note that good health promotes economic development activities while environmental resources have several implications on human health and economy.

The environmental effects of fuelwood consumption include: desertification, soil erosion and high rate of soil fertility loss. The rate of fuelwood consumption far exceeds reforestation rate. The current economic condition of the country greatly favours continuous utilization of fuelwood for domestic and other energy purposes. Sambo (2006) estimates that about 350,000 hectares of forest and natural vegetation are lost annually due to various factors, with a much lower afforestation rate of 50,000 hectares/year. Fuelwood consumption is one of the major factors accounting for deforestation in Nigeria. The adverse effects of deforestation are many and demand urgent intervention. Deforestation leads to soil erosion, affects groundwater level and negatively affects soil fertility.

Forests are habitat for wild animals. Once the forest is removed, the animals become homeless and flee to another place for their survival. Forests also act as sink for carbon dioxide, a green house gas that causes climate change and global warming. The impacts of climate change are numerous and its consequences are beyond what a poor nation like Nigeria can afford. In addition, most of the trees and shrubs used as fuelwood are part of the biological diversity that provides food, medicine and aesthetic value to the nation. A lot of trees and shrubs of various species have disappeared.

Continuous dependence on fuelwood for domestic energy will increasingly have negative effects on the economy and social life of the people. Women and children are involved in the collection and transportation 
of fuelwood from the bush to the home. On many occasions depending on the situation, they have to travel far and wasted their time in the process. At times, women have to carry heavy loads to reduce the number of trips required to provide fuelwood for their households. They may head-load fuelwood as heavy as 35 kilogram or more over a long distance of up to $10 \mathrm{~km}$ in often difficult terrain. Carrying such heavy loads over long distance has adverse health implications on the women especially those within the child-bearing age. This may damage spice and cause difficulties during pregnancies and childbirth because substantial amount of energy is involved coupled with poor access to good medical facilities in most of the rural areas in Nigeria.

Fuelwood scarcity may cause changes in the nutritional intake of the people. It may lead to fewer meals being cooked as well as meals being cooked less well. Fuelwood shortage may lead to shift to food items that require less energy to cook, which may be nutritionally poor. Most of the protein food of plant origin such as cowpeas, soybeans, lima beans, groundnut and so on, required large amount of heat and often take longer time to cook unlike starchy foods that require small amount of heat and short time to cook.

\section{The Need for Alternative Energy Source for Domestic Use}

Nigeria is expected to experience shortfall in fuelwood supply. This is because the nation forest area is depleting. Nigerian forest has experienced an annual average forest change of -2.4 between 1990 and 2005 (Human Development Report, 2007/2008). This shows that between 2005 and 2009, the nation's forest is expected to have diminished further due to increase in population and harsh economic condition. As a result, many trees and shrubs will be harvested for energy purpose. The country is therefore expected to witness an imbalance between demand and supply of fuelwood.

Population growth translates into increase in the demand for energy. Nigeria is a country that is currently experiencing increase in human population. This will lead to increase in the demand for fuelwood both in the rural and urban areas unless there is a reversal of attitude. The increase in the rate of urbanization in the country may not alter the dependence on fuelwood for domestic energy. This is because most of the urban dwellers that are economically poor would still rely on fuelwood for their various domestic energy needs, most especially for cooking.

The above scenarios show that the nation forests are in danger. Nigeria cannot afford to allow its forests to continue to experience an increasing rate of deforestation due to the various economic and social impacts. Therefore appropriate measures must be taken to reverse the ugly situation.

\section{The War Forward}

The need to provide adequate domestic energy supply through other energy sources apart from fuelwood is a necessity in the process of achieving efficient energy utilization and protection of forest resources in Nigeria. The various available natural energy options in the country should be utilized for meeting domestic energy needs in Nigeria. There is a strong need to develop the various energy resources in the country.

The issue of climate change must be taken into consideration by ensuring a great reduction the volume of carbon dioxide being emitted into the atmosphere through energy generation and utilization. Clean energy sources that emit very low to zero quantity of carbon dioxide into the atmosphere should be given a very priority in energy development agenda of the country.

However fossil fuel has to be depended upon as a major energy source in the country due to its large deposit in the country. The need to depend on fossil fuel is also based on the fact that Nigeria has the capability to develop and install the necessary infrastructure like refineries, depots and means of transportation that will ensure adequate energy supply in the country.

Pending the time when clean energy sources are available for domestic use in Nigeria, kerosene and gas should be provided for the Nigerian populace. In the first instance, Nigeria has the potential of making 
kerosene available to both the rural and urban dwellers in the country because there is abundant crude oil and we have the capability to refine it. This will ensure adequate production of petroleum products locally.

\section{References}

Adetunji, M.O, Adesiyan, I.O and Sanusi. W.A. (2007). Household Energy Consumption Pattern in Oshogbo Local Government Area of Osun State. Pakistan Journal of Social Sciences 4 (1) 9-13.

Central Bank of Nigeria (CBN, 2007). Annual Report and Statement of Accounts.

Earth Trends Energy and Resources in Nigeria. www.Earthtrend.wri.org.

Energy Commission of Nigeria (ECN,2003). National Energy Policy

Ikuponisi, F. S. (2006). The Status of Renewable Energy in Nigeria. Background Brief For Energetic Solutions. An International Conference on Making Renewable Energy a Reality

Iwayemi, A. (2008). Nigeria's Dual Energy Problems: Policy Issues and Challenges. Internal association for Energy Economics pp17-21

Kerby, A. (2008). CCCC, Kick the Habit. AUN Guide to Climate Neutrality. A United Nation Environmental Protection Publication

Sambo, A.S (2005).Renewable Energy for Rural Development: The Nigerian Perspective.ISESCO Science and Technology Vision, Vol 1, 12-22

Sambo A. S. (2006). Strategic Development in Renewable Energy in Nigeria.. International Association of Energy Economics.pp15-20

Williams, M. and Pinto, F.(2000). Energy Supply and Demand Integration Workshop On Alternative Energy Strategies. MIT Press Cambridge, pp 230-257.

World Development Indicators (2006) 
